\title{
Effects of organic carbon, organic nitrogen, inorganic nutrients, and iron additions on the growth of phytoplankton and bacteria during a brown tide bloom
}

\author{
Christopher J. Gobler*, Sergio A. Sañudo-Wilhelmy \\ Marine Sciences Research Center, SUNY at Stony Brook, Stony Brook, New York 11794-5000, USA
}

\begin{abstract}
Although nutrient inputs are the most commonly cited cause of brown tide blooms of Aureococcus anophagefferens on Long Island, New York, there is no consensus as to which nutrient(s) stimulates $A$. anophagefferens growth in the field. To evaluate the ability of dissolved organic carbon (DOC as glucose), dissolved organic nitrogen (DON as urea), nitrate, phosphate and iron to enhance A. anophagefferens growth during blooms, 10 nutrient enrichment experiments were conducted over the course of a brown-tide bloom during May, June and July of 1998 in West Neck Bay (WNB), Long Island, USA, using whole bay water. During the experiments, A. anophagefferens densities ranged from $1 \times 10^{4}$ to $5 \times 10^{5} \mathrm{cells} \mathrm{ml}^{-1}$, representing between 2 and $90 \%$ of algal biomass. Brown tide growth changed as a function of ambient nutrient levels during experiments, as the bloom shifted from organic carbon to N-limitation when nitrate levels in WNB decreased from elevated (2 to $20 \mu \mathrm{M}$ ) to low $(<0.5 \mu \mathrm{M})$ levels. Contrary to current hypotheses that organic nitrogen fuels $A$. anophagefferens bloom formation and inorganic nitrogen can repress it, brown tide growth in response to equimolar nitrate and urea additions was nearly identical during experiments. Additions of nitrate or urea either had no effect or significantly decreased the relative abundance of the brown tide among the algal community during experiments. In contrast, augmentation of $A$. anophagefferens growth and decreases in non-brown-tide phytoplankton (NBTP) growth during organic carbon (glucose) additions resulted in significant increases in the relative abundance of brown tide among phytoplankton. Simultaneous enhancement of bacterial growth by glucose additions indicated a possible A. anophagefferens-NBTPbacterial interaction by which monospecific brown tides may be initiated. Therefore, it is hypothesized that processes introducing copious amounts of labile DOC during $A$. anophagefferens blooms, such as leakage or remineralization of NBTP blooms, could promote monospecific brown tides.
\end{abstract}

KEY WORDS: Brown tide $\cdot$ Harmful algal blooms $\cdot$ Bacteria $\cdot$ Phytoplankton · Nutrients $\cdot$ Organic carbon · Iron Resale or republication not permitted without written consent of the publisher

\section{INTRODUCTION}

For over 15 yr, brown tide blooms of the pelagophyte Aureococcus anophagefferens have occurred in multiple estuaries across the Northwest Atlantic coast (Bricelj \& Lonsdale 1997). Annual recurrence of brown

*Present address: Natural Science Division, Southampton College of Long Island University, Southampton, New York 11968, USA. E-mail: cgobler@southampton.liu.edu tides on Long Island have led to the collapse of the scallop fishery (Argopecten irradians irradians; Bricelj \& Kuenstner 1989), and have decimated eelgrass beds (Dennison et al. 1989). While multiple factors have been implicated as potential bloom initiators (reviewed by Bricelj \& Lonsdale 1997), nutrients have been most frequently cited (Cosper et al. 1987, 1989, 1990, 1993, Dzurica et al. 1989, Keller \& Rice 1989, Smayda \& Villareal 1989, Milligan 1992, Nixon et al. 1994, Gobler \& Cosper 1996, Berg et al. 1997, LaRoche et al. 1997, 
Breuer et al. 1999). To date, a consensus as to which nutrient(s) control $A$. anophagefferens growth in the field does not exist, as inorganic nitrogen (Nixon et al. 1994, LaRoche et al. 1997), dissolved organic carbon (DOC) (Dzurica et al. 1989, Milligan \& Cosper 1997, Breuer et al. 1999), dissolved organic nitrogen (DON) (Dzurica et al. 1989, Berg et al. 1997, LaRoche et al. 1997), urea (Dzurica et al. 1989, Berg et al. 1997) and iron (Milligan 1992, Cosper et al. 1993, Gobler \& Cosper 1996) have all been hypothesized to influence initiation of brown tides.

Aureococcus anophagefferens is capable of efficiently taking up several organic nitrogen compounds in laboratory cultures (Dzurica et al. 1989) and during bloom events (Berg et al. 1997). In the Peconic Estuary of Long Island, brown tides commonly occur in drought years when inputs of nitrate-rich groundwater are greatly reduced (LaRoche et al. 1997). Thus, it has been suggested that brown tides are largely controlled by the balance of organic and inorganic nutrients, with DON levels that are elevated relative to those of inorganic nitrogen favoring bloom initiation (LaRoche et al. 1997). Iron may also be an important nutritional factor for the growth of $A$. anophagefferens based on (1) multiple laboratory investigations which have indicated that $A$. anophagefferens cultures grow maximally with high Fe levels (Cosper et al. 1993, Benmayor 1996, Gobler \& Cosper 1996), and (2) natural and manipulated $\mathrm{Fe}$ additions which have stimulated growth of $A$. anophagefferens field populations (Milligan 1992, Cosper et al. 1993, Gobler \& Cosper 1996). Additionally, other laboratory research also suggests that $A$. anophagefferens may utilize DOC to supplement its cellular carbon requirements (Dzurica et al. 1989), particularly during the lower light conditions that can persist during blooms (Milligan \& Cosper 1997).

Interactions between heterotrophic bacteria and Aureococcus anophagefferens could play an important role in brown tide occurrence. Since bacteria, like the brown tide, can obtain most of their cellular $\mathrm{N}$ from organic forms (Billen 1984, Wheeler \& Kirchman 1986, Kirchman et al. 1994), it is possible that $A$. anophagefferens competes with bacteria for $\mathrm{N}$-sources and/or organic $\mathrm{C}$ during bloom events. The limited number of protozoans known to consume $A$. anophagefferens (Caron et al. 1989, Mehran 1996), also efficiently graze heterotrophic bacteria (Sherr et al. 1986, Caron et al. 1991). While both top-down and bottom-up controls on bacterial and $A$. anophagefferens populations may be similar, their dynamics during brown tide events have not been investigated.

The purpose of this study was to evaluate the capability of several nutrients to enhance the growth of Aureococcus anophagefferens during a 1998 two- month brown tide bloom in a Long Island embayment, West Neck Bay (WNB). Field experiments were conducted over the course of the bloom using additions of nutrients which have been hypothesized to stimulate or repress brown tide events, including inorganic and organic nitrogen, organic carbon, iron and phosphate. Simultaneous measurement of organic (DOC, urea), inorganic (nitrate, ammonium, phosphate) and trace metal $(\mathrm{Fe})$ nutrients in the water column of WNB allowed us to evaluate growth responses in the light of ambient conditions. The results indicated that the nutrients stimulating the growth of $A$. anophagefferens changed over the course of the bloom and that these nutrients often simultaneously augmented the growth of heterotrophic bacteria. In contrast to these populations, the growth of non-A. anophagefferens phytoplankton was consistently enhanced by $\mathrm{N}$ (urea and nitrate) additions.

\section{METHODS}

Ten experiments were conducted during May (31), June $(4,8,12,22,26)$ and July $(3,8,14,21)$ of 1998 at West Neck Bay (WNB). WNB is a small, shallow ( 4 m), enclosed embayment on Shelter Island within the Peconic Estuary of Long Island (Fig. 1). WNB is of particular interest to brown tide research, since blooms are common to this embayment, even when they may be absent in the neighboring Peconic Estuary (Bricelj \& Lonsdale 1997). Seawater from WNB was collected in a triplicate 41 fluorinated HDPE bottle at a depth of $0.5 \mathrm{~m}$ using trace-metal-clean protocols (Flegal et al. 1991, Sañudo-Wilhelmy et al. 1996) and was kept cool $\left(<10^{\circ} \mathrm{C}\right)$ and dark after collection. Within $2 \mathrm{~h}$ of collection, $50 \mathrm{ml}$ of seawater was transferred to trace-metalclean $60 \mathrm{ml}$ polycarbonate flasks in a HEPA laminar flow hood to prevent trace metal and bacterial contamination. Triplicate flasks were amended with sodium nitrate $(10 \mu \mathrm{M})$, urea $(5 \mu \mathrm{M}=10 \mu \mathrm{M} \mathrm{N})$, sodium phosphate $(0.62 \mu \mathrm{M})$, iron sulfate $(1 \mu \mathrm{M})$, or glucose $(17 \mu \mathrm{M}$ $=100 \mu \mathrm{M} \mathrm{C}$ ), or were left unamended as a control treatment. The concentrations of these additions were similar to previously observed changes in these nutrients in the water column of WNB during brown tides (Gobler 1999). Furthermore, additions followed Redfield proportions with regard to $\mathrm{N}$ and $\mathrm{P}(16: 1)$. Both $\mathrm{N}$ additions and controls were used in every experiment, whereas glucose was used in all experiments after 8 June. Iron was a treatment in all experiments except for 8 and 12 June, and phosphate was not added during the 8, 12 or 22 June, or 8 and 14 July experiments. All nutrient stocks were cleaned of trace metals with Chelex-100 ion exchange resin (Bruland 1980), filtersterilized $(0.2 \mu \mathrm{m})$, and frozen before use. The single 
exception to this procedure was iron sulfate, which was made fresh for each experiment with trace-metalclean, filtered $(0.2 \mu \mathrm{m})$ seawater. Ambient levels of silicate in the WNB water column ranging from 35 to $60 \mu \mathrm{M}$ during the course of our experiments assured silicate-replete conditions for diatoms.

Amended samples were incubated in polycarbonate flasks at the same temperature found in WNB during water collection under $125 \mu \mathrm{E} \mathrm{m} \mathrm{m}^{-2} \mathrm{~s}^{-1}$ of light on a light:dark cycle which mimicked summer conditions on Long Island (14 h:10 h). The average incoming solar radiation during daylight hours (06:00 to $20: 00 \mathrm{~h}$ ) to Long Island during June and July 1998 was $2140 \mu \mathrm{E} \mathrm{m} \mathrm{m}^{-2} \mathrm{~s}^{-1}$ (V. Cassella, Brookhaven National Lab, pers. comm.), and the average extinction coefficient in the WNB water column during the experiments was 2.26 (Gobler 1999). Therefore, the $125 \mu \mathrm{E} \mathrm{m} \mathrm{m}^{-2} \mathrm{~s}^{-1}$ used in our experiments was equivalent to the light levels found at $1.4 \mathrm{~m}$ in the water column of WNB during this period, or $\sim 4 \%$ of incident radiation. After $48 \mathrm{~h}$, samples from each flask were filtered for chlorophyll a ( $\mathrm{chl}$ a) onto GF/F glassfiber filters. In addition, aliquots from each flask were preserved to a final concentration of $1 \%$ glutaraldehyde in sterile polycarbonate test tubes for cell counts, using a $10 \%$ stock solution made from $0.2 \mu \mathrm{m}$ filtered WNB seawater.

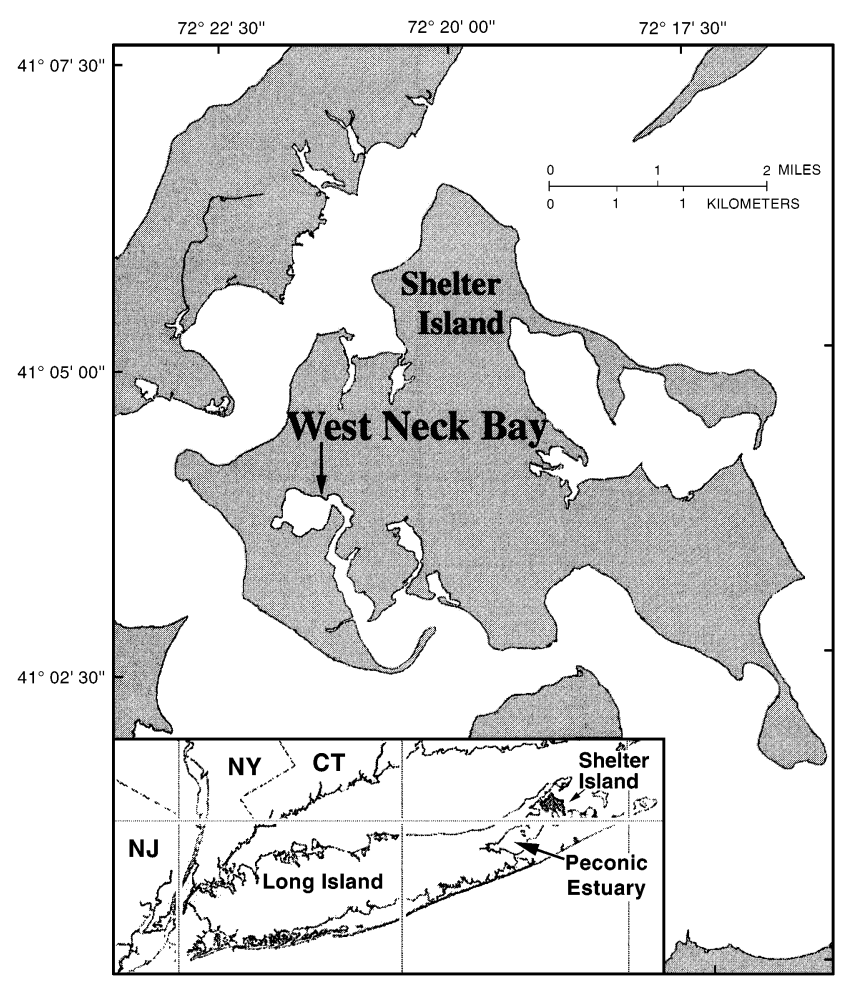

Fig. 1. Study site, West Neck Bay, Shelter Island, New York
Particulate organic carbon (POC) and chl a samples were collected at time, $t, t=0$ on precombusted GF/F glass-fiber filters, and stored frozen. DOC and nutrient samples were collected in the field using acid-cleaned, polypropylene capsule filters $(0.2 \mu \mathrm{m}$; MSI Inc., Westborough, MA, USA) and were immediately stored on ice. Within $2 \mathrm{~h}$ of collection, DOC samples were acidified with quartz-distilled nitric acid and frozen along with DON and nutrient samples. DOC samples were analyzed in duplicate by high-temperature catalytic oxidation using a Shimadzu TOC-5000 total organic carbon analyzer (Sugimura \& Suzuki 1988, Benner \& Strom 1993). Duplicate POC samples were dried at $60^{\circ} \mathrm{C}$ and then measured on a Carlo Erba NA 1500 NCS system (Sharp 1974). Chl a was analyzed by standard fluorometeric methods (Parsons et al. 1984). Standard spectrophotometric methods were used to analyze nitrate (Jones 1984), urea (Newell et al. 1967), ammonium, phosphate and silicate (Parsons et al. 1984). One or $10 \mathrm{~cm}$ cell path lengths were employed during spectrophotometric nutrient analysis, depending on ambient concentrations. Measurements of $\mathrm{J}$. Sharp's (University of Delaware) intercalibration DOC samples were within $5 \%$ of the consensus value. Measurements of NIST 16326 standard reference material for POC were within $8 \%$ of certified values. Recoveries $\left(\right.$ mean \pm 1 SD) of SPEX Certi-Prep ${ }^{\text {INC }}$ (Metuchen, NJ, USA) inorganic nutrient standard-reference material were $104 \pm 5 \%$ for nitrate, $96 \pm 6 \%$ for ammonium and $103 \pm 5 \%$ for phosphate. Precombustion of glassware and GFF filters provided adequately low blanks for DOC and POC/PON ( $<10 \%$ of lowest sample).

Sampling material for collection of dissolved Fe samples from WNB was prepared using trace-metal-clean techniques (Flegal et al. 1991, Sañudo-Wilhelmy et al. 1996). Dissolved Fe samples were collected with a peristaltic pump through Teflon tubing and trace-metalclean, polypropylene capsule filters $(0.2 \mu \mathrm{m})$ (Flegal et al. 1991, Sañudo-Wilhelmy et al. 1996). Tubing was extended on a bamboo pole $4 \mathrm{~m}$ upwind and lowered to a depth of $1 \mathrm{~m}$. In a class-100 trace-metal-clean facility, samples were acidified, and pre-concentrated by organic solvent extraction using ammonium 1-pyrrolidinedithiocarbamate/diethylammonium diethyldithiocarbamate (APDC/DDDC) as described by Bruland et al. (1985). Fe concentrates were analyzed on a Hitachi Zeeman-8100 graphite furnace, atomic-absorption spectrophotometer (GFAAS) employing standard addition techniques. Our methods yielded a relative standard deviation (RSD) of $9 \%$ and a detection limit ( $3 \times$ standard deviation of the average blank value) of $32 \mathrm{pM}$ for the analysis of dissolved Fe.

Aureococcus anophagefferens and bacterial densities in preserved samples were determined by directcount methods employing fluorochromes and an epi- 
fluorescent microscope. A. anophagefferens cells were enumerated by staining cells which were gently filtered $(<5 \mathrm{kPa})$ onto a $0.8 \mu \mathrm{m}$ black polycarbonate filter with an immunofluorescent label, as described by Anderson et al. (1989). A minimum of 100 cells were counted per sample in at least 25 fields to yield a relative standard deviation of $7 \%$ for replicate counts of the same sample $(n=10)$ at cell densities of $1 \times 10^{5}$ cells $\mathrm{ml}^{-1}$, approximating average densities during experiments. To ensure accurate results, the immunofluorescent technique was compared to counts performed with a hemacytometer on a light microscope. The 2 techniques yielded statistically identical results using A. anophagefferens cultures isolated from WNB (Mehran 1996, Culture CCMP 1708) and Great South Bay, Long Island (Cosper 1987, Culture CCMP 1784), at cell densities of $1 \times 10^{5}$ cells ml ${ }^{-1}$.

Bacteria were enumerated according to Porter \& Feig (1980) using the fluorochrome 4',6-di-amidinophenyl-indole (DAPI). Small-volume subsamples (0.5 to $1 \mathrm{ml}$ ) were incubated with $0.02 \mathrm{mg} \mathrm{DAPI} \mathrm{ml}^{-1}$ for $10 \mathrm{~min}$, then were gently filtered $(<5 \mathrm{kPa})$ onto $0.2 \mu \mathrm{m}$ black polycarbonate filters within $24 \mathrm{~h}$ of preserving the samples. Filters were stored dark and frozen until counted. A minimum of 200 cells were counted per sample in at least 10 fields to yield a relative standard deviation of $8 \%$ for replicate counts of the same sample $(n=10)$ at cell densities of $3 \times 10^{6}$ cells ml $^{-1}$, approximating average densities during experiments. Blank counts using $0.2 \mu \mathrm{m}$-filtered seawater were prepared in a manner identical to samples, and were always $<1 \%$ of sample densities. Examination of each field of DAPI-stained samples under blue and green light excitation ensured that autotrophic picoplankton were not counted as heterotrophic bacteria.

The amount of chl a due to the presence of brown tide in each sample was estimated by assuming a constant chl a per cell value for Aureococcus anophagefferens $\left(0.035 \pm 0.003 \mathrm{pg} \mathrm{cell}^{-1}\right.$ for nutrient-replete cultures; Gobler 1995) and multiplying this value by the A. anophagefferens density. Levels of chl a from nonbrown-tide phytoplankton (NBTP) were calculated as the difference between total chl a and chl a due to $A$. anophagefferens. Although such calculations could be biased by variability in cellular chlorophyll concentrations arising from changes in light and nutrient levels during experiments, such approximations have been used successfully in the past to compare A. anophagefferens biomass to that of the total algal community (Gobler 1999, Schaffner 1999, D. Caron unpubl. data). Net specific growth rates of $A$. anophagefferens, the non-A.anophagefferens phytoplankton community, and heterotrophic bacteria during the incubations were determined in doublings per day according to Guillard (1973).
The relative abundance of Aureococcus anophagefferens was calculated as a percentage of total phytoplankton biomass ([A. anophagefferens $\mathrm{chl}$ a/total chl a] $\times 100$ ). Simultaneous consideration of changes in brown tide and NBTP biomass during our experiments demonstrated which nutrient additions enhanced the relative abundance of $A$. anophagefferens within the phytoplankton community. NBTP and $A$. anophagefferens biomass was converted to $\mathrm{C}$ using a $\mathrm{C}: \mathrm{chl}$ a $\left(\mathrm{g} \mathrm{C} \mathrm{g} \mathrm{chl} \mathrm{a}^{-1}\right)$ ratio of 99 (average at WNB during experiments; Gobler 1999), whereas a $C$ content of $20 \mathrm{fg} \mathrm{cell}^{-1}$ was used as a conversion for bacteria (Lee \& Fuhrman 1987). Using these conversions, the summed C content of NBTP, A. anophagefferens and bacterial populations was $109 \pm$ $12 \%$ (mean $\pm 1 \mathrm{SD}$ ) of ambient measured POC levels.

\section{RESULTS}

\section{Brown tide, NBTP, and heterotrophic bacterial dynamics at WNB}

During experiments, Aureococcus anophagefferens densities ranged from $1 \times 10^{4}$ to $5 \times 10^{5}$ cells ml ${ }^{-1}(0.5$ to $17 \mathrm{\mu g} \mathrm{l}^{-1}$ ), while non- $A$. anophagefferens chl a varied between 2 and $28 \mu \mathrm{g} \mathrm{l}^{-1}$, and heterotrophic bacterial densities varied between 2.3 and $8.9 \times 10^{6}$ cells ml ${ }^{-1}$ (Fig. 2A). During the first 3 experiments (31 May, 4 and 8 June), non- $A$. anophagefferens phytoplankton comprised $\sim 95 \%$ of total POC, while bacteria and the brown tide each represented 2 to $4 \%$ of $\mathrm{C}$ biomass (Fig. 2B). Beginning on 12 June, brown tide biomass began to increase until it reached a maximum on 3 July, when it represented $>85 \%$ of total POC. Over the same period (12 June to 3 July), NBTP C decreased to a low of $11 \%$ of POC, while bacteria comprised about $5 \%$ of the POC during this period. During the final 3 experiments $(8,14,21$ July), NBTP returned to dominance, comprising around $66 \%$ of $\mathrm{C}$ biomass, while Aureococcus decreased to $\sim 25 \%$ of POC, and the bacterial portion increased to $10 \%$ by 21 July. Size-fractionated chl a measurements and epifluorescent microscopic observations indicated dominance by small, autotrophic flagellates among the NBTP throughout our experiments; $\sim 90 \%$ of the total chl a was $<5 \mu$ m (Gobler 1999).

\section{Dissolved nutrient concentrations in WNB}

The dissolved nutrient regime at WNB changed markedly over the course of our experiments. During late May and June of 1998, water-column nitrate levels were elevated (average $=7 \mu \mathrm{M}$; Fig. 3A). DOC levels were relatively low during this initial period, ranging 

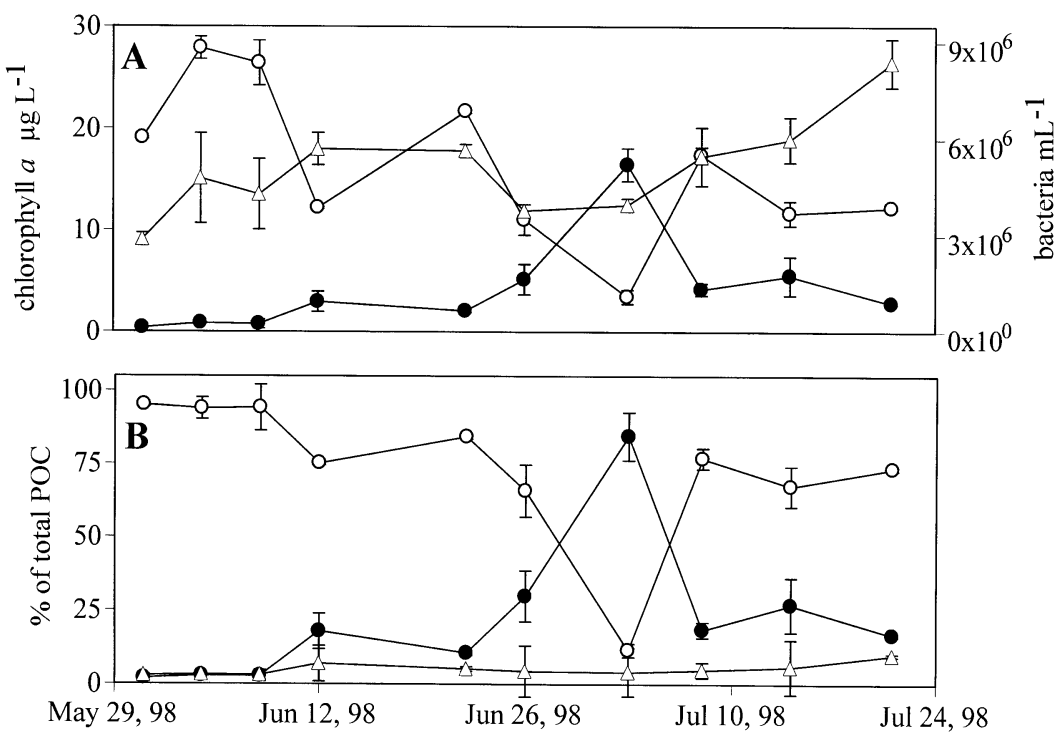

Fig. 2. Variation in Aureococcus anophagefferens, NBTP, and heterotrophic bacteria in the water column of WNB during experiments. (A) Chlorophyll a for A. anophagefferens $(\bullet)$ and NBTP $(O)$ and cell density for bacteria $(\triangle)$, (B) percent of total measured POC represented by $A$. anophagefferens $(\bullet)$, NBTP $(O)$ and bacteria $(\Delta)$. Error bars represent \pm 1 SD $(\sigma)$ of triplicate measurements

\section{Pre-brown tide bloom-maximum experiments: elevated nitrate, low DOC}

During the first 2 pre-bloom-maximum experiments (31 May, 4 June), nutrient additions (nitrate, urea, iron, phosphate) did not change bacterial or Aureococcus anophagefferens net growth rates compared to control treatments (Fig. 4A,B), with the exception of the urea addition on 4 June which resulted in a significant decrease in the growth of $A$. anophagefferens (Fig. $4 \mathrm{~B}_{;} \mathrm{p}<0.05$, Student's $t$-test). In contrast, glucose additions significantly enhanced brown tide and bacterial growth rates above controls during the next 3 experiments $(8,12$, 22 June; Fig. 4C-E; $p<0.05, t$-test). During all pre-bloom peak-period experiments, NBTP growth was significantly augmented by nitrate and urea from 230 to $260 \mu \mathrm{M}$, excluding 31 May, when levels were notably higher (298 $\mu \mathrm{M}$; Fig. 3A). In July, nitrate levels in WNB significantly decreased (average = $0.27 \mu \mathrm{M})$ from those in June, while DOC concentrations increased to over $310 \mu \mathrm{M}$ by 21 July (Fig. 3A). Concentrations of ammonium and urea were relatively low $(<0.5 \mu \mathrm{M})$ over the course of the experiments (Fig. 3B). Dissolved phosphate increased from $<0.1 \mu \mathrm{M}$ in early June to $>0.85 \mu \mathrm{M}$ in late July. Dissolved Fe levels varied from $>500 \mathrm{nM}$ on 31 May, to $<50 \mathrm{nM}$ in early July, and were generally higher during the May and June experiments (average $=213 \mathrm{nM}$ ) than during the July experiments (average $=109$ nM; Fig. 3C).

Based on the dynamics of brown tide cell-densities, nitrate levels and DOC concentrations in WNB in 1998, we have grouped our 10 experiments into 3 categories: (1) Pre-brown tide bloom-maximum with elevated nitrate and lower DOC = 31 May, 4, 8, 12, 22 June; during these experiments Aureococcus anophagefferens represented a small, but increasing fraction of $\mathrm{C}$ biomass (2 to $20 \%$ ) at WNB (Fig. 2B). (2) Brown tide bloom-maximum with transitional nitrate and $\mathrm{DOC}=$ 26 June and 3 July; during these experiments $A$. anophagefferens rose to its peak densities (33 and $85 \%$ of Ci Fig. 2B). (3) Post-brown tide bloom-maximum, low nitrate and elevated DOC $=8,14,21$ July; during these experiments $A$. anophagefferens remained at moderate densities, and was approximately $20 \%$ of $\mathrm{C}$ biomass (Fig. 2B).
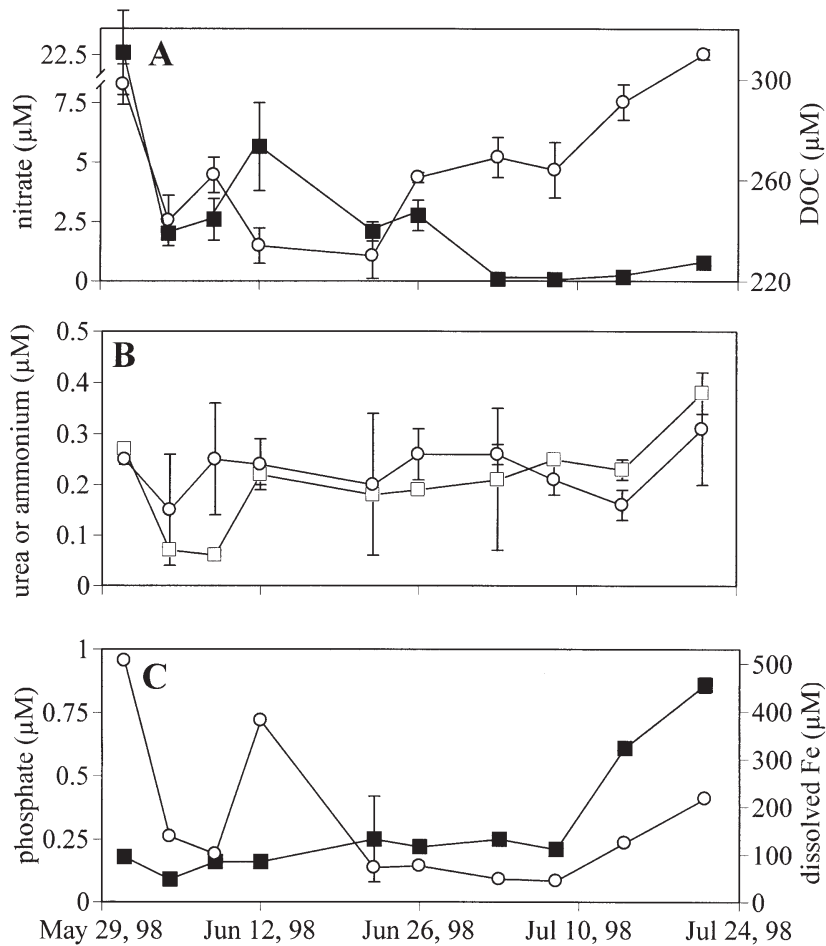

Fig. 3. (A) Variation in nitrate ( $\mathbf{\square})$ and DOC (O) in water column of WNB during experiments, $(B)$ variation in urea $(\mathrm{O})$ and ammonium ( $\square)$, (C) variation in phosphate (ם) and dissolved $\mathrm{Fe}(\mathrm{O})$ in water column of WNB during experiments. Error bars represent $\pm 1 \mathrm{SD}(\sigma)$ of duplicate measurements. Dissolved Fe measurements were not replicated 

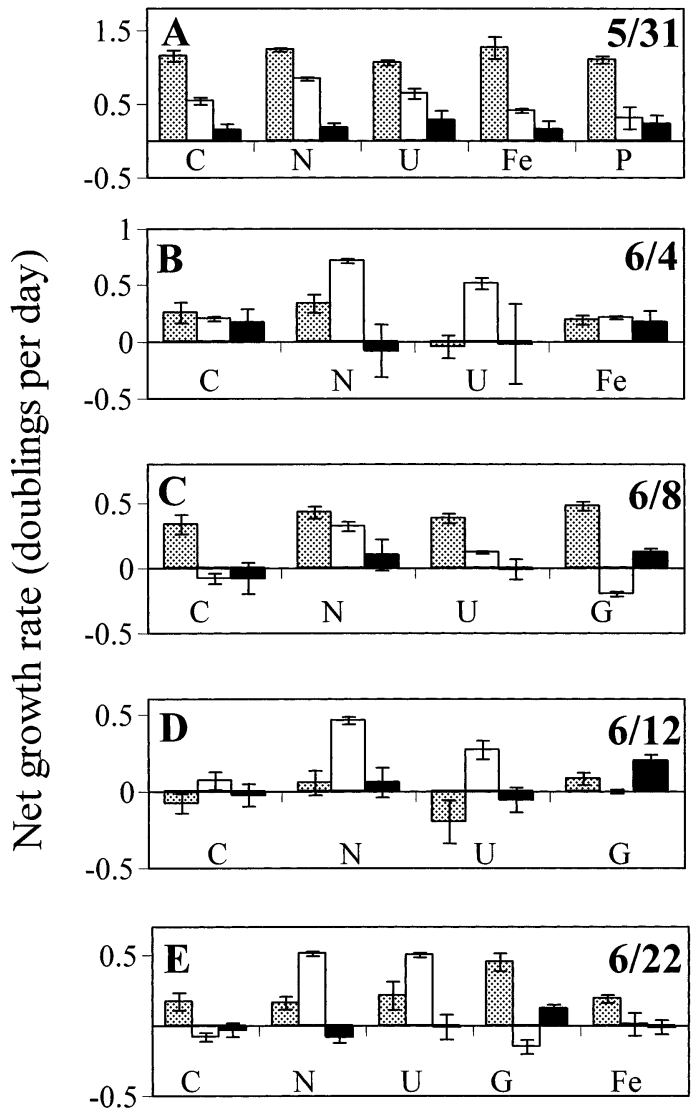

Fig. 4. Net growth rates of Aureococcus anophagefferens (gray bars), NBTP (white bars) and bacteria (black bars) during pre-bloom-maximum experiments on: (A) 31 May, (B) 4 June, (C) 8 June, (D) 12 June, and (E) 22 June. Within each experiment, abbreviations for treatments are: $\mathrm{C}=$ control $_{i} \mathrm{~N}=$ nitrate; $\mathrm{U}=$ urea; $\mathrm{Fe}=$ iron; $\mathrm{P}=$ phosphate; and $\mathrm{G}=$ glucose. Error bars represent \pm 1 SD $(\sigma)$ of triplicate measurements

additions (Fig. $4 ; \mathrm{p}<0.05, t$-test). The single exception to this was the 31 May experiment, when nitrate, but not urea, augmented NBTP growth above that of controls (Fig. 4A). While nitrate also increased NBTP growth significantly more than urea in the next 3 experiments $\left(4,8,12\right.$ June) (Fig. $4 \mathrm{~A}-\mathrm{D}_{i} \mathrm{p}<0.05, t$-test), there was no difference in the NBTP response to the 2 types of $\mathrm{N}$-additions in the 22 June experiment (Fig. 4E).

The relative abundance of Aureococcus anophagefferens increased from 4 to $>20 \%$ of algal biomass during pre-bloom-maximum experiments (dashed lines in Fig. 5). Since N-additions increased NBTP biomass and had no effect on brown tide densities, these additions significantly decreased the relative abundance of A. anophagefferens among the phytoplankton community compared to controls during pre-bloom peak experiments $(\mathrm{p}<0.05, t$-test $)$. However, glucose additions significantly increased the relative abundance of brown tide during these experiments $(\mathrm{p}<0.05, t$-test), due to both $A$. anophagefferens growth enhancement $(8,12,22$ and June; Fig. 4C-E) and repression of NBTP growth (8 June; Fig. $4 C_{i} p<0.05, t$-test).

\section{Brown tide-maximum experiments: transitional nitrate and DOC}

During bloom-maximum experiments (26 June and 3 July), nitrate, urea and glucose all significantly enhanced brown tide net growth rates above control treatments (Fig. $6 ; \mathrm{p}<0.05, t$-test). Bacterial growth was significantly augmented above controls by glucose and urea in these experiments (Fig. 6; p $<0.05$, $t$-test). NBTP growth was significantly enhanced over unamended controls by both types of $\mathrm{N}$ in these ex-
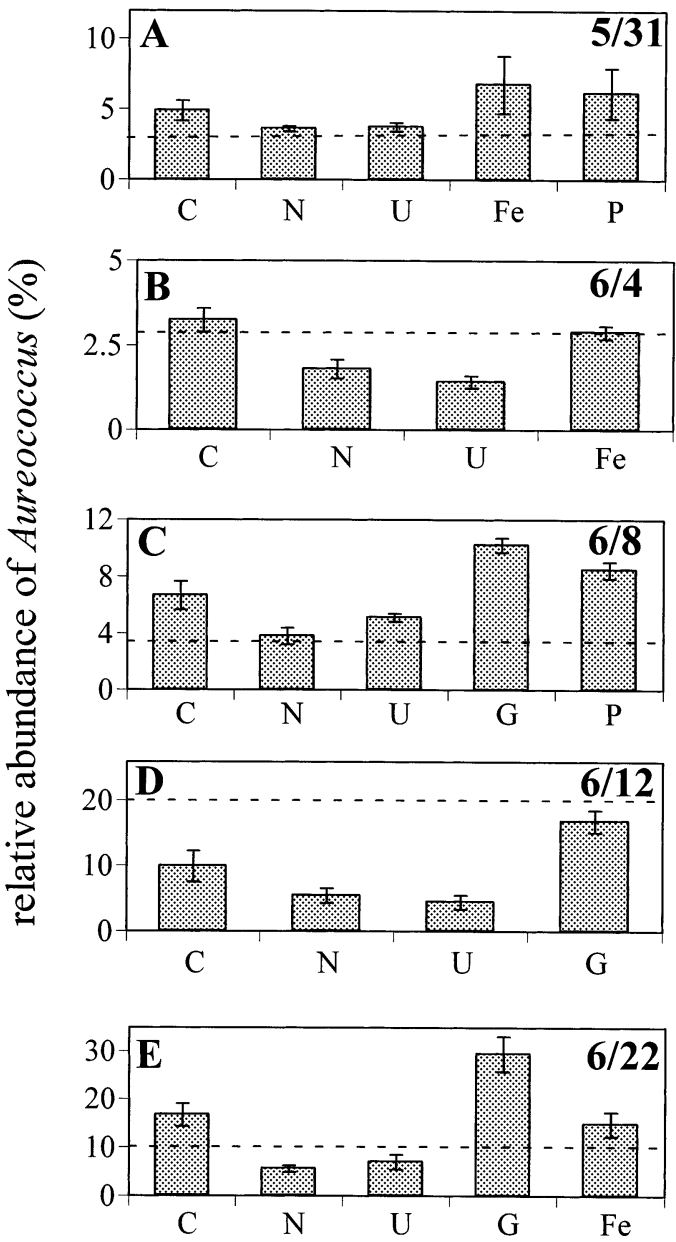

Fig. 5. Relative abundance of Aureococcus anophagefferens within experimental flasks at the end of each pre-bloommaximum experiment conducted on (A) 31 May, (B) 4 June, (C) 8 June, (D) 12 June, and (E) 22 June. Dashed line indicates relative abundance at the beginning of each experiment. Further details as in Fig. 4 legend 


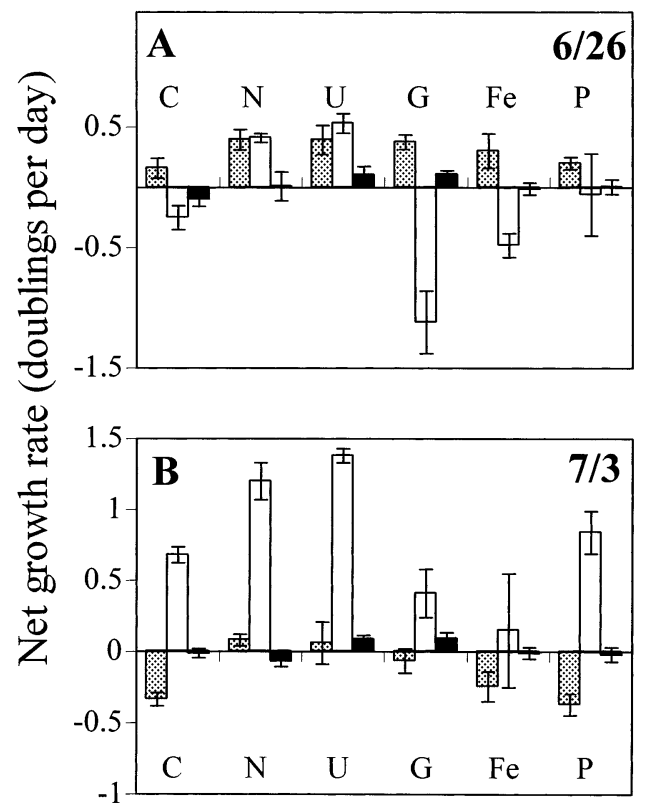

Fig. 6. Net growth rates of Aureococcus anophagefferens (gray bars), NBTP (white bars) and bacteria (black bars) during bloom-maximum experiments on (A) 26 June, (B) 3 July.

Further details as in Fig. 4 legend

periments (Fig. $6 ; \mathrm{p}<0.05, t$-test), and NBTP urea net growth rates were significantly greater than NBTP nitrate net growth rates (Fig. $6 ; \mathrm{p}<0.05, t$-test).

At the peak of the brown tide bloom, Aureococcus anophagefferens accounted for 30 and $85 \%$ of total algal biomass on 26 June and 3 July, respectively (Fig. 7). Glucose additions significantly repressed NBTP growth compared to controls in both bloom maximum experiments which, along with $A$. anophagefferens growth augmentation, contributed to a significant increase in brown tide abundance among phytoplankton above controls (Fig. $7 ; \mathrm{p}<0.05, t$-test). The repression of NBTP growth by the Fe addition compared to controls on 26 June (Fig. 6A) also led to a significant increase in brown tide abundance in this treatment compared to unamended controls (Fig. 7A; $\mathrm{p}<0.05, t$-test).

\section{Post-brown tide bloom-maximum experiments: low nitrate, elevated DOC}

During the post-bloom-maximum period $(8,14$, 21 July), the response of Aureococcus anophagefferens to nutrient additions was more similar to that of the NBTP than bacteria (Fig. 8). Nitrate and urea magnified the net growth of NBTP above unamended control treatments during all 3 experiments (Fig. 8.; p $<0.05$, $t$-test). While this was also the case for the brown tide during the 8 and 14 July experiments (Fig. $8 \mathrm{~A}_{1} \mathrm{~B}_{i} \mathrm{p}<$ $0.05, t$-test), A. anophagefferens experienced rapid negative net growth rates in all treatments of the 21 July experiment (Fig. 8C). Glucose significantly augmented bacterial net growth rates above controls during only the 8 July experiment (Fig. 8A; $p<0.05$, $t$-test).

The brown tide represented approximately 18 to $30 \%$ of algal biomass at $t=0$ of post-bloom-maximum experiments (dashed lines in Fig. 9). In a manner similar to the pre-bloom-maximum and bloom-maximum periods, glucose additions during this period significantly decreased NBTP growth rates compared to controls (Fig. 8A, $\mathrm{B} ; \mathrm{p}<0.05, t$-test), and thus magnified the relative abundance of Aureococcus anophagefferens in the 8 and 14 July experiments above controls (Fig. 9A, $; ; p<0.05, t$-test). While Fe significantly decreased NBTP growth rates in the 14 July experiment (Fig. $8 \mathrm{~B}_{i} \mathrm{p}<0.05, t$-test) the relative abundance of $A$. anophagefferens was not significantly altered. Finally, larger brown tide growth rates relative to those of NBTP in the urea treatment of the 14 July experiment led to a significant increase in the relative abundance of brown tide compared to controls (Fig. 9B; $\mathrm{p}<0.05, t$-test).

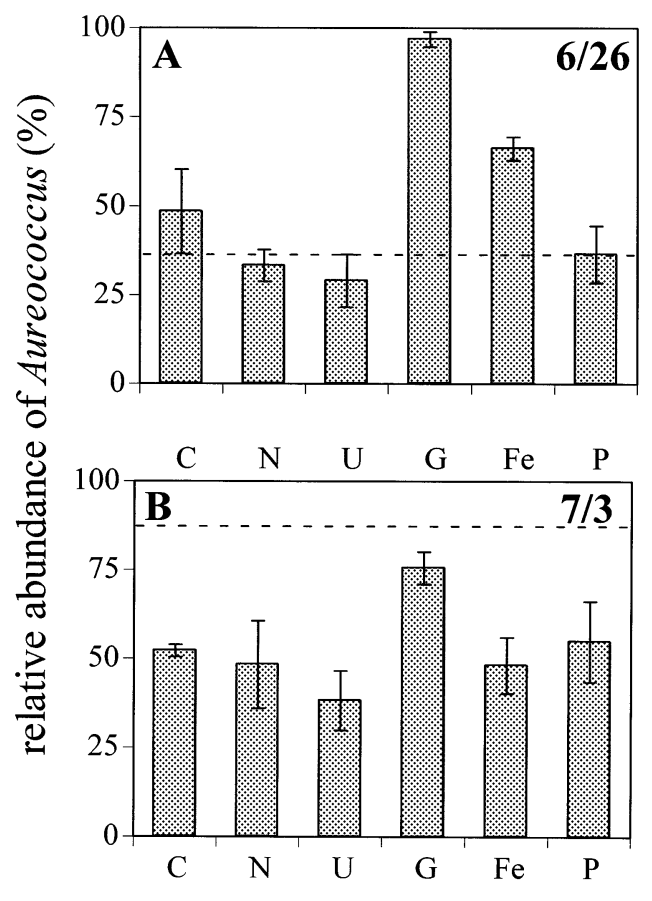

Fig. 7. Relative abundance of Aureococcus anophagefferens within experimental flasks at the end of each bloom-maximum experiment conducted on (A) 26 June, (B) 3 July. Dashed line indicates relative abundance of Aureococcus at the beginning of each experiment. Further details as in Fig. 4 legend 


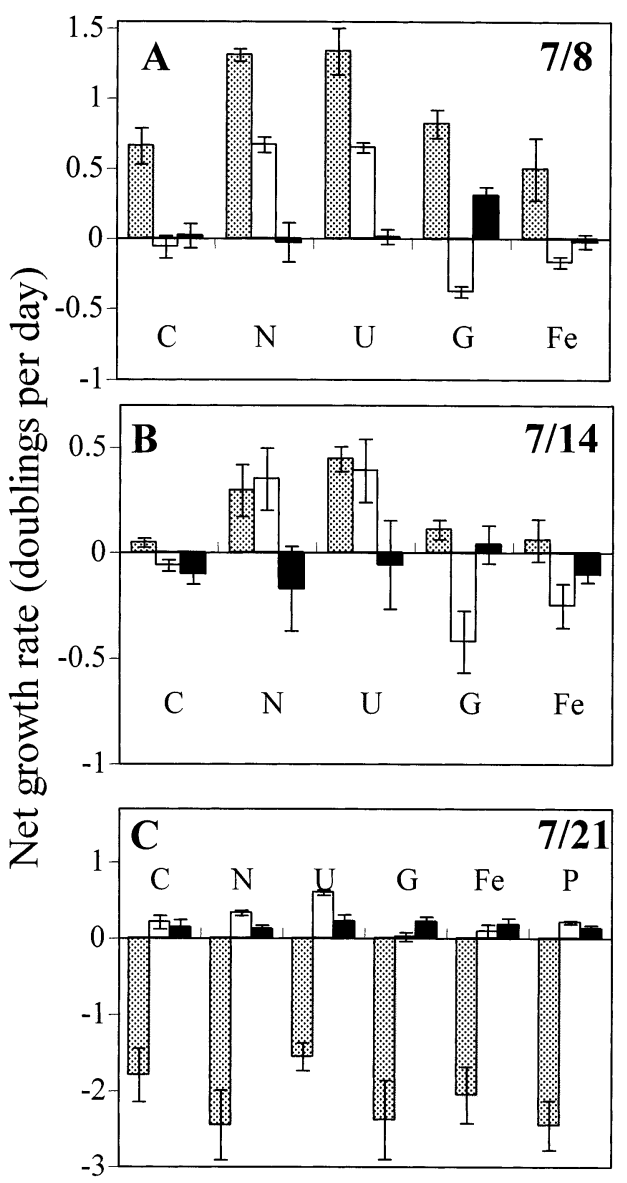

Fig. 8. Net growth rates of Aureococcus anophagefferens (gray bars), NBTP (white bars) and bacteria (black bars) during post-bloom-maximum experiments on (A) 8 July, (B) 14 July, (C) 21 July. Further details as in Fig. 4 legend

\section{DISCUSSION}

These experiments demonstrate that the nutrients capable of stimulating brown tide growth can vary in response to ambient nutrient levels (Figs. 3,4,6 \& 8). During pre-bloom-maximum experiments in which Aureococcus anophagefferens growth was unaffected by $\mathrm{N}$-additions (31 May, 4, 8, 12, 22 June; Fig. 4), ambient nitrate levels in WNB were elevated (average = $7 \mu \mathrm{M}$; Fig. 3A). When nitrate in the water column of WNB dropped below $0.5 \mu \mathrm{M}$ (Fig. 3A), N-additions stimulated the growth of the brown tide $(3,8,14$ July; Figs. $6 \mathrm{~B} \& 8 \mathrm{~A}, \mathrm{~B})$. The 26 June experiment was the single exception to this pattern. A similar but less distinct trend was observed between ambient DOC concentrations in the water column of WNB and the response of $A$. anophagefferens to glucose additions. Mean DOC levels found during experiments in which glucose augmented $A$. anophagefferens growth
(252 $\mu \mathrm{M}, 8$ June to 3 July; Figs. 3A, 4 \& 6) were lower than DOC concentrations in experiments when glucose had no effect ( $288 \mu \mathrm{M}, 8$ to 21 July; Figs. 3A \& 8). However, the unknown lability of the bulk DOC pool makes comparisons of absolute DOC levels difficult to establish (Amon \& Benner 1994).

These experiments also indicate that the nutrient augmenting Aureococcus anophagefferens growth rates can differ from that affecting the total phytoplankton community, but may be more similar to that of heterotrophic bacteria. During pre-bloom-peak experiments (31 May to 22 June), N-additions enhanced NBTP growth rates, but had no effect on bacteria or $A$. anophagefferens (Fig. 4). During this same period, and extending into early July (8 June to 3 July), glucose additions stimulated both brown tide and bac-

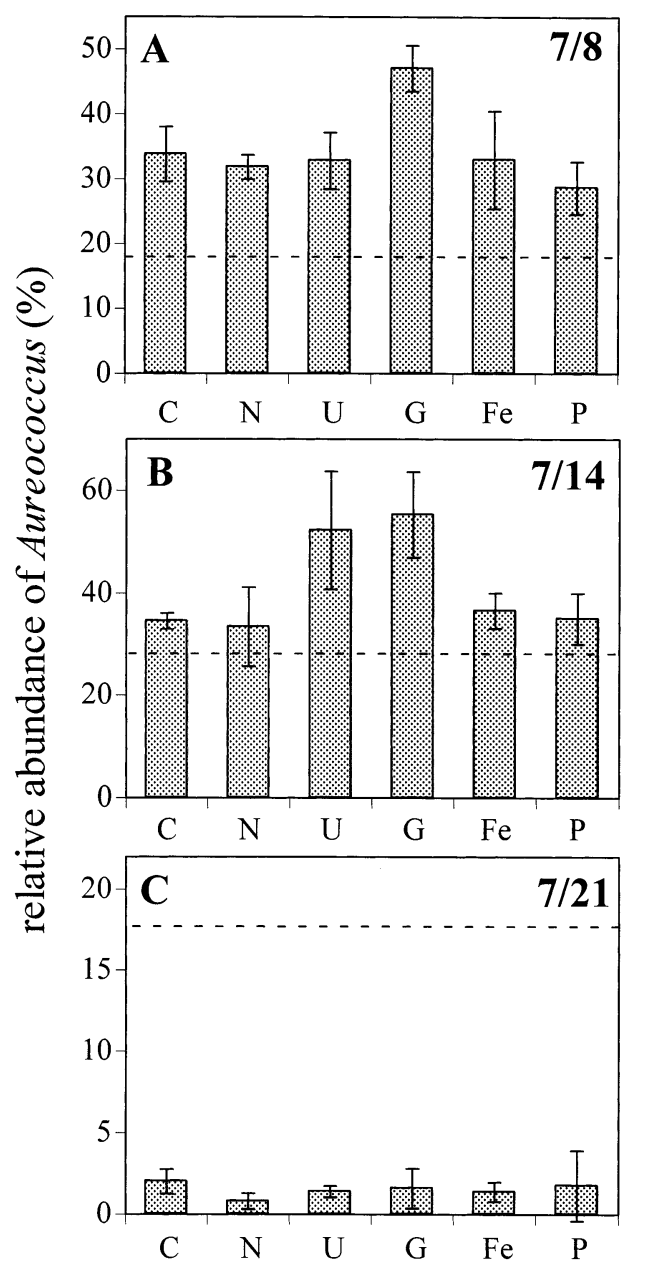

Fig. 9. Relative abundance of Aureococcus anophagefferens within experimental flasks at the end of each post-bloommaximum experiment conducted on (A) 8 July, (B) 14 July, (C) 21 July. Dashed line indicates relative abundance at the beginning of each experiment. Further details as in Fig. 4 legend 
teria growth, but yielded lower NBTP growth (Figs. 4 \& $6)$. This trend ended during the post-bloom maximum experiments (8 and 14 July), when both NBTP and $A$. anophagefferens growth were augmented by N-additions (Fig. 8A,B). These results could have important implications with regard to the nutrient and microbial dynamics of brown tide blooms in Long Island embayments as discussed in the following sections.

\section{Nitrogen}

It has been proposed that inorganic $\mathrm{N}$ inputs can repress the formation of brown tides (Keller \& Rice 1989, LaRoche et al. 1997), while organic N inputs stimulate them (LaRoche et al. 1997), and that urea is the organic $\mathrm{N}$ compound most important for sustaining Aureococcus anophagefferens blooms (Berg et al. 1997). The decrease in relative abundance of $A$. anophagefferens among phytoplankton in our N-addition treatments when ambient nitrate levels were relatively high (average $>7 \mu \mathrm{M} ; 31$ May, 4, 8, 12, 22 June) supports the hypothesis that eutrophic conditions (>10 $\mu \mathrm{M}$ labile $\mathrm{N}$ ) do not favor the initiation of monospecific brown tides (Keller \& Rice 1989, Nixon et al. 1994, LaRoche et al. 1997). In addition, the only instance in which $\mathrm{N}$ increased the relative abundance of $A$. anophagefferens among phytoplankton, it was caused by urea and not nitrate (14 July; Fig. 9B). However, the response of $A$. anophagefferens in the remainder of our $\mathrm{N}$-addition treatments was somewhat unexpected for 2 reasons. First, with the exception of the 14 July experiment, $A$. anophagefferens responded identically to nitrate (inorganic $\mathrm{N}$ ) and urea (organic N) additions in all experiments (Figs. 4,6 \& 8). Second, although DON has been thought to explain brown tide bloom initiation on Long Island (LaRoche et al. 1997), DON additions of urea decreased or had no measurable effect on the relative abundance of $A$. anophagefferens among phytoplankton in any experiment, except that on 14 July (Figs. 5,7 \& 9).

These results open important new perspectives with regard to $\mathrm{N}$ and brown tides on Long Island. Aureococcus anophagefferens can grow efficiently on urea in culture (Dzurica et al. 1989), and it has been reported that most of the $\mathrm{N}$ assimilated by blooms is from urea (Berg et al. 1997). However, the failure of urea additions to increase the relative abundance of $A$. anophagefferens among phytoplankton in 9 of 10 experiments (Figs. 5,7\&9) indicates that it may be a poor proxy for the DON that actually initiates brown tides (Gobler 1999). Most algal species can take up urea and have uptake rates comparable with those of A. anophagefferens (Carpenter et al. 1972, Antia et al. 1975, Dzurica et al. 1989, Lomas et al. 1996). Results presented by Berg et al. (1997) indicating the preference of brown tides for urea were derived from experiments conducted at Shinnecock Bay, Long Island, over $3 \mathrm{~d}$ in which $A$. anophagefferens was already established as the dominant alga. Since our results demonstrate that the nutrient which influences brown tide growth can change over the course of a bloom, Berg et al.'s results were probably not representative of conditions that lead to bloom initiation. Furthermore, there may be substantial differences in $\mathrm{N}$ sources, and thus brown tide nutrient-limitation, between Shinnecock and WNB. WNB is an inland bay which has a copious supply of nitrate-rich groundwater inputs (Gobler 1999), while Shinnecock is an open bay which exchanges with the more oligotrophic Atlantic Ocean (Berg et al. 1997).

The results presented here suggest that if $\mathrm{N}$ inputs contribute to monospecific brown tides, they would differ from the types of $\mathrm{N}$-additions used in our experiments, which consistently failed to increase the dominance of Aureococcus anophagefferens among phytoplankton (Figs. 5, $7 \&$ 9). While $10 \mu \mathrm{M}$ urea (Carpenter et al. 1991) and nitrate (this study) can be found on occasion in bays which host brown tides, typical ambient concentrations during blooms for each of these compounds are <0.5 $\mu \mathrm{M}$ (Gobler 1999). It is possible that a steady input of $\mathrm{N}$ at lower concentrations would be more favorable for a monospecific brown tide bloom than a single $10 \mu \mathrm{M}$ addition, particularly since small cells such as $A$. anophagefferens can have their $\mathrm{N}$ uptake kinetics saturated at moderate $\mathrm{N}$ concentrations (Eppley et al. 1969, Lomas et al. 1996). Alternatively, inputs of organic $\mathrm{N}$ compounds more enriched in carbon than urea, such as amino acids or amino sugars, may be more likely to lead to a monospecific brown tide, since organic carbon additions consistently increased the relative abundance of $A$. anophagefferens among phytoplankton. It is also possible that the brown tide's mode of gaining dominance is simply to grow slowly using DON sources which are more refractory and thus less available to other algal species.

The change in the type of $\mathrm{N}$ which yielded maximal growth rates of NBTP during our experiments was probably a function of ambient conditions found in WNB. During the pre-bloom-maximum experiments, when NBTP growth rates on nitrate were significantly greater than for other treatments, including urea (Fig. 4A-D), there were elevated levels of nitrate in WNB (Fig. 3A). With copious amounts of nitrate present, the algal community was probably well adapted to efficiently utilize high ambient levels, and less capable of metabolizing urea (Glibert et al. 1995).

During bloom-maximum experiments (26 June, 3 July), urea yielded NBTP growth rates significantly greater than in all other treatments, including nitrate 
additions (Fig. 6A). These experiments were toward the end of a mixed algal bloom at WNB, when nitrate levels were decreasing to $<0.5 \mu \mathrm{M}$ (Fig. 2A). Hence, cells present at this time were likely to be adapted to efficiently utilize regenerated $\mathrm{N}$ sources, such as urea (Glibert et al. 1995), which was probably being produced at a high rate during the bloom maximum (Turley 1985, Cho et al. 1996). Urea additions failed to enhance NBTP growth significantly more than nitrate during 2 of 3 post-bloom-peak experiments (Fig. 8). This result may indicate a preference of resident phytoplankton for other types of recycled $\mathrm{N}$ (ammonium, amino acids, DON, Glibert 1982 1993, Bronk et al. 1994, 1998), which are also generated at elevated rates after peaks in algal density (Bidigare 1983, Glibert 1993).

Urea additions also stimulated bacterial growth rates above unamended controls during the bloom-maximum experiments (26 June and 3 July; Fig. 6). This was somewhat unexpected, since bacteria are typically seen as net producers of urea and not consumers (Turley 1985, Cho et al. 1996). While some culture work has shown that urea can contribute significantly to bacterial N demand (Cho 1988), it is possible that bacterial growth enhancement was not due to direct utilization, but instead was a function of phytoplankton exudation of DOC. The experiments in which urea caused enhancement of bacterial growth rates were also the only incubations in which urea increased phytoplankton growth significantly more than any other treatment, including nitrate additions (Fig. 6). Since glucose (DOC) additions also stimulated bacterial growth in these experiments, the observed enhancement of bacterial growth in the urea incubations could have been a function of actively growing phytoplankton leaking labile DOC, which was then utilized by bacteria (Billen \& Fontigny 1987, Blight et al. 1995, Sanders \& Purdie 1998).

\section{Dissolved organic carbon}

In contrast to $\mathrm{N}$-additions, DOC additions of glucose consistently resulted in a significant increase in the relative abundance of Aureococcus anophagefferens among phytoplankton (Figs. 5, $7 \&$ 9). The most dramatic impact of the glucose additions was observed during the 26 June experiment, when $A$. anophagefferens abundance increased from 31 to $97 \%$ of algal biomass (Fig. 7A). That increase paralleled the monospecfic brown tide bloom which occurred the same week in WNB (Fig. 2).

Bacterial heterotrophy is traditionally considered a major removal process for labile DOC in marine environments, which can regenerate $\mathrm{N}$ (Wright \& Hobbie
1966, Kirchman et al. 1991, Amon \& Benner 1994). However, bacteria metabolizing a high $\mathrm{C}: \mathrm{N}$ substrate $(>10)$, such as glucose, become a sink, not a source, for $\mathrm{N}_{i}$ and thus become competitors with phytoplankton for DIN (Goldman et al. 1987, Kirchman et al. 1990, Goldman \& Dennett 1991). Therefore, it is probable that increases in brown tide growth were due to direct carbon uptake and not $\mathrm{N}$ remineralization by bacteria. The failure of $\mathrm{N}$ to stimulate Aureococcus anophagefferens growth in 3 out of 5 of the experiments in which DOC enhanced growth (Fig. 4) also suggests that remineralized $\mathrm{N}$ was not responsible for augmenting brown tide growth during glucose additions. While laboratory studies have demonstrated heterotrophic $\mathrm{C}$ assimilation by several phytoplankton species, including A. anophagefferens (Droop 1974, Neilson \& Lewin 1974, Dzurica et al. 1989, Lewitus \& Caron 1991, Lewitus \& Kana 1995), these experiments are the first field examples of DOC additions stimulating the growth of brown tides, or, to our knowledge, any harmful algal bloom species. In phytoplankton, cellular polysaccharides serve as a $\mathrm{C}$ buffer system; they are built up during photosynthesis and broken down at night for energy and protein synthesis (Mague et al. 1980, Cuhel et al. 1984). This ability to build internal polysaccharide pools with both photosynthesis and heterotrophic uptake of $\mathrm{C}$ would reduce net respiration losses by $A$. anophagefferens, and possibly enhance growth.

The role of DOC in the growth of Aureococcus anophagefferens may also be a function of the ambient light levels, as algal heterotrophy often increases under reduced light conditions (Droop 1974, Neilson \& Lewin 1974, Lewitus \& Caron 1991, Lewitus \& Kana 1995). Previous work has hypothesized that light limits productivity in Long Island's Peconic (Bruno et al. 1983) and Great South (Lively et al. 1983) Bays, which now host sporadic $A$. anophagefferens blooms (Bricelj \& Lonsdale 1997). During experiments in which DOC enhanced brown tide growth, the $1 \%$ light depth at WNB was 3-fold shallower than spring conditions ( $>6 \mathrm{~m}$ in mid-May to $<2 \mathrm{~m}$ in June; Gobler 1999). Furthermore, the light used in our experiments was equal to levels found at $1.4 \mathrm{~m}$ in WNB (see 'Methods'), and below irradiances yielding maximal photosynthesis in A. anophagefferens (Milligan \& Cosper 1997). Hence, heterotrophic $\mathrm{C}$ uptake during the experiments could have enhanced $A$. anophagefferens net $\mathrm{C}$ acquisition by $A$. anophagefferens, and probably yielded a competitive advantage over strictly autotrophic species.

The simultaneous increase in bacterial growth rates and decrease in phytoplankton growth rates observed during glucose additions (Figs. 5, 7 \& 9) has been observed previously (Parker et al. 1975, Parsons et al. 1980, Spies et al. 1983, Miller et al. 1997). This phe- 
nomenon could be due to competition for inorganic $\mathrm{N}$ sources between phytoplankton and bacteria. Estuarine bacteria normally obtain most of their cellular $\mathrm{N}$ from amino acids (Billen \& Fontigny 1987, Coffin 1989) and can make $\mathrm{N}$ available to phytoplankton through remineralization of such organics when substrate C:N is <10 (Goldman et al. 1987). However, when presented with a labile substrate with a high $\mathrm{C}: \mathrm{N}$ ratio (>10) such as glucose, bacteria consume ammonium (Goldman et al. 1987, Kirchman et al. 1990, Goldman \& Dennett 1991, Shiah \& Ducklow 1995, Miller et al. 1997), and/or nitrate (Parker et al. 1975, Parsons et al. 1980, Spies et al. 1983) instead of amino acids (Kirchman et al. 1990, Goldman \& Dennett 1991, Sanders \& Purdie 1998). Since Aureococcus anophagefferens is capable of utilizing amino acids (Dzurica et al. 1989, Berg et al. 1997, Mulholland et al. 1998), a switch to DIN utilization by bacteria during glucose additions would reduce competition for amino acids between bacteria and A. anophagefferens, and thus could account for increased $A$. anophagefferens growth. Alternatively, NBTP experiencing negative growth rates in glucose treatments may be leaking organic $\mathrm{N}$ which could be utilized by A. anophagefferens (Bronk et al. 1994, Nguyen \& Harvey 1997). Whether it be due to the elimination of non- $A$. anophagefferens phytoplankton, the increased availability of the amino acid pool, DON leaked from non-A. anophagefferens phytoplankton, or a combination of these events, DOCenhanced bacterial growth rates may help create a niche for monospecific brown tides.

The release of carbohydrates is a common phenomenon among phytoplankton, which occurs during stationary and exponential phase growth (Mague et al. 1980, Myklestad et al. 1989, Kepkay et al. 1993, Biddanda \& Benner 1997), nutrient limitation (Ittekkot et al. 1981), and grazing (Williams 1975). Glucose is the most abundant monosaccharide carbohydrate in seawater (Mopper et al. 1980), and is the most abundant aldose in phytoplankton (Biersmith \& Benner 1998). The primary source of glucose in marine systems is phytoplankton (Hanson \& Snyder 1980, Ittekkot et al. 1981, Griffiths et al. 1982, Rich et al. 1996). Therefore, the use of glucose treatments in these experiments represented a proxy for the natural release of phytoplankton-derived, labile DOC. The stimulation of Aureococcus anophagefferens growth and relative abundance by glucose additions suggests this is an enrichment process which could contribute to monospecific brown tides on Long Island. This enrichment process is also consistent with field observations of brown tide blooms at WNB which can begin as mixed assemblage blooms and become monospecific as nonA. anophagefferens phytoplankton die (Fig. 2A) and leak DOC (Fig. 3A).

\section{Iron}

While Fe has previously been cited as an important growth factor for brown tide blooms (Milligan 1992, Cosper et al. 1993, Gobler \& Cosper 1996), Fe additions failed to measurably stimulate the growth of the brown tide in any of our experiments (Figs. 4,6 \& 8). This may be due, in part, to the relatively high Fe levels within WNB (Fig. 3C). A comparison of dissolved Fe concentrations in the Peconic Estuary has shown that WNB has the highest dissolved Fe levels in this system (Gobler \& Sañudo-Wilhelmy unpubl. obs.). Furthermore, mean dissolved Fe levels present during our experiments were generally above concentrations known to limit Aureococcus anophagefferens growth (<100 nM, Boyer et al. 1999). Hence, if A. anophagefferens were to experience Fe limitation, it would probably not be in WNB. This conclusion is consistent with the results of Cosper et al. (1993), who demonstrated that growth of $A$. anophagefferens was augmented with iron additions in experiments at Quantuck Bay, Long Island, but not at WNB.

During our 26 June experiment, Fe additions repressed NBTP growth and thus increased the relative abundance of $A$. anophagefferens among the algal community from 33 to $>70 \%$ (Fig. 7A). Since Fe pulses are known to precede monospecific brown tides (Gobler \& Cosper 1996, Gobler \& Sañudo-Wilhelmy unpubl. obs.), such inputs could be contributing toward $A$. anophagefferens dominance by eliminating competing phytoplankton. Saturating Fe levels could prevent selected algal species from assimilating other essential trace elements (Sunda 1994, Sunda \& Huntsman 1995, Magdalena Santana-Cosicno et al. 1997). Alternatively, if additions Fe co-preciptated orthophosphate out of solution (Stumm \& Morgan 1981) it would have deprived autotrophic phytoplankton of $\mathrm{P}$, but would have allowed $A$. anophagefferens to proliferate, since it can use organic $P$ (Dzurica et al. 1989).

\section{Brown tide-bacterial dynamics}

Since Aureococcus anophagefferens and heterotrophic bacteria may use similar resources (organic nutrients; Dzurica et al. 1989, Kirchman et al. 1994) and may be consumed by similar predators (heterotrophic protozoans; Sherr et al. 1986, Caron et al. 1989, Lonsdale et al. 1996, Mehran 1996), it is possible that the success of one of these populations will be at the cost of the other. While the results presented here do not provide an absolute characterization of this interaction, some preliminary conclusions can be drawn based on the observed growth responses of each population. 
Considering the growth rates of these 2 populations, brown tide control treatments experienced positive net growth rates during 7 of our 10 experiments, and averaged 0.4 doublings $\mathrm{d}^{-1}$, whereas bacterial controls demonstrated positive growth in only 3 of 10 experiment, and averaged 0.05 doublings $\mathrm{d}^{-1}$ (Figs. 4, 6 \& 8). These results suggest that heterotrophic bacteria were either growing more slowly or were under greater biological removal pressure than Aureococcus anophagefferens (e.g. grazing, viral lysis). Furthermore, during the peak of the brown tide at WNB in 1998 (26 June to 3 July; Fig. 2A), there was a significant decrease in the abundance of heterotrophic bacteria. This decrease occurred despite an increase in bacterial stimulating factors, including chl $a$, and DOC (Figs. 2A \& 3B; Cole et al. 1982). If the observed decrease in bacterial abundance was a result of protozoan grazing (Sherr et al. 1986), A. anophagefferens may have benefited by reduced competition for organic nutrients with bacteria and/or decreased grazing pressure from protozoan and/or regeneration of organic nutrients (Bidigare 1983, Nagata \& Kirchman 1992). Despite some differences in the growth response of heterotrophic bacteria and $A$. anophagefferens in WNB and in control treatments, these 2 populations did react similarly to glucose additions in 6 experiments $(8,12,22,26$ June, and 3 and 14 July; Figs. 4, 6 \& 8). Since glucose additions were large $(100 \mu \mathrm{M})$ compared to ambient DOC levels (average $=250 \mu \mathrm{M}$ ), it is possible that bacteria and A. anophagefferens compete for labile DOC during brown tide events.

While the stimulation of bacterial growth by the addition of organic substrates is a common observation in estuarine environments (Goldman et al. 1987, Kirchman et al. 1990, Shiah \& Ducklow 1995, Miller et al. 1997), this response was absent in our final 2 experiments (14 and 21 July; Fig. 8B,C). Ambient DOC concentrations (mean $\pm \mathrm{SD}$ ) in WNB during these experiments $(300 \pm 13 \mu \mathrm{M}$; Fig. 3A) were significantly greater than in experiments when glucose caused enhancement of bacterial growth rates $\left(253 \pm 15 \mu \mathrm{M}_{i}\right.$ Fig. 3A; $\mathrm{p}<0.05$; $t$-test). This suggests that ambient concentrations may have been sufficient to support maximal bacterial growth rates. It is of interest that Aureococcus anophagefferens densities were simultaneously reduced to $<10^{4}$ cells $\mathrm{ml}^{-1}$ in all treatments of our final experiment (Fig. 8C) as well as in WNB during the same week (Fig. 2A). Such a rapid decrease in brown tide abundance is indicative of viral lysis of a bloom (Milligan \& Cosper 1994, Gobler et al. 1997). It is also consistent with results of previous experiments which have demonstrated that viral lysis of $A$. anophagefferens results in a direct trophic transfer of $\mathrm{C}$ to bacteria (Gobler et al. 1997). If bacteria were presented with such a labile $\mathrm{C}$ supply, one would not expect further
DOC (glucose) additions to enhance bacterial growth (Fig. 8C). The suggested trophic transfer of cellular material from $A$. anophagefferens to bacteria is supported by the observation of maximal bacteria densities at the end of this final experiment $\left(>8 \times 10^{6}\right.$ cells $\mathrm{ml}^{-1}$, Fig. 2A).

\section{Implications for brown tides on Long Island}

To extrapolate the results presented here to brown tides in other Long Island embayments, it is important to consider the ambient nutrient conditions in WNB during our experiments. Nitrate concentrations in WNB during our pre-bloom-maximum experiments were markedly higher than normal (average $=7 \mu \mathrm{M}$ vs 1997 average $=0.2 \mu \mathrm{M}$ ) due to unusually high groundwater flow at this time (Gobler 1999). Since these conditions may be similar in Great South Bay (GSB), which is known to have seasonally elevated groundwater flow and inorganic nutrients (Bokuniewicz 1980, Carpenter et al. 1991), organic carbon additions may also stimulate brown tides in GSB. Conversely, the low ambient nitrate found during our July experiments is probably more typical of the rest of the Peconic Estuary, which usually has low DIN levels $(<1 \mu \mathrm{M}$; SCDHS 1985-1998). Since N limited the brown tide's growth during this low DIN period at WNB, it is possible that $\mathrm{N}$ is also commonly limiting Aureococcus anophagefferens blooms in the Peconics.

Nitrogen is the most common limiting element for phytoplankton in coastal marine ecosystems (Ryther \& Dunstan 1971, Nixon \& Pilson 1983). Whether N is limiting phytoplankton production in estuaries that are currently plagued by brown tide blooms has been debated for many years. Work by Ryther \& Dunstan (1971) in Great South Bay (GSB) cited sub-Redfield $\mathrm{N}: \mathrm{P}(<4.0)$ and significantly enhanced growth of phytoplankton with $\mathrm{N}$-additions as evidence of N-limitation. However, nutrient and productivity studies by Kaufman et al. (1983) concluded that 'phytoplankton are probably never N-limited' in GSB. Bruno et al. (1983) concluded that primary productivity in the Peconic Estuary, where WNB is located, is light- and temperature-limited, and that $\mathrm{N}$ concentrations do not affect primary productivity.

Those findings starkly contrast with the results presented here, which demonstrate that even during elevated nitrate conditions, the short-term $(2 \mathrm{~d})$ growth rates of the total phytoplankton community are augmented by $\mathrm{N}$-additions. Observations of low DIN:DIP ratios (2.1) across the Peconics from 1996 to 1997 also support the contention of $\mathrm{N}$ limitation in this estuary (Gobler 1999), perhaps due in part to the rapid regeneration of P (Nixon \& Pilson 1983, Smith 
1984). If our results are representative of the Peconic Estuary, they suggest that ambient $\mathrm{N}$ supply has decreased or changed since earlier studies (Bruno et al. 1983). If these systems are currently N-limited, a species with unique strategy for circumventing low inorganic $\mathrm{N}$ levels, such as refractory DON utilization by Aureococcus anophagefferens, would now have a competitive advantage that would allow it to dominate.

Acknowledgements. We are grateful for helpful comments on this manuscript from R. Aller, N. Fisher, R. Flegal, D. Hutchins, C. Lee and 3 anonymous reviewers. We thank D. Lonsdale and G. Taylor for use of their laboratory space and equipment. We thank K. Black for access to WNB. This research was supported by NOAA's Coastal Ocean Programs award NA66 RG0368 for New York Sea Grant Institute.

\section{LITERATURE CITED}

Amon RW, Benner R (1994) Rapid cycling of high-molecular weight dissolved organic matter in the ocean. Nature 369: 549-552

Anderson DM, Kulis DM, Cosper EM (1989) Immunofluorescent detection of the 'brown tide' organism, Aureococcus anophagefferens. In: Cosper EM, Bricelj VM, Carpenter EJ (eds) Novel phytoplankton blooms: causes and impacts of recurrent brown tides and other unusual blooms. Springer-Verlag, Berlin, p 213-228

Antia NJ, Berland DJ, Maestrini SY (1975) Comparative evaluation of certain organic and inorganic sources for growth of marine microalgae. J Mar Biol Assoc UK 55:519-539

Benmayor S (1996) Environmental conditions influencing viral-algal interactions of the brown tide picoplankter, Aureococcus anophagefferens. Masters thesis, Marine Sciences Research Center, SUNY, Stony Brook, NY

Benner R, Strom M (1993) A critical evaluation of the analytical blank associated with DOC measurements by hightemperature catalytic oxidation. Mar Chem 41:153-160

Berg GM, Gilbert PM, Lomas MW, Burford M (1997) Organic nitrogen uptake by the chrysophyte Aureococcus anophagefferens during a brown tide bloom event. Mar Biol 129:377-387

Biddanda B, Benner R (1997) Carbon, nitrogen, and carbohydrate fluxes during the production of particulate and dissolved organic matter by marine. Limnol Oceanogr 42: 506-518

Bidigare RR (1983) Nitrogen excretion by marine zooplankton. In: Carpenter EJ, Capone DG (eds) Nitrogen in the marine environment. Academic Press, New York, p 411-458

Biersmith A, Benner R (1998) Carbohydrates and freshly produced dissolved organic matter. Mar Chem 63:131-144

Billen G (1984) Heterotrophic utilization and regeneration of nitrogen. In: Hobbie JE, Williams PJL (eds) Heterotrophic activity in the sea. Plenum Press, New York, p 313-355

Billen G, Fontigny A (1987) Dynamics of a Phaeocystis dominated spring bloom in Belgian coastal waters. II. Bacterioplankton dynamics. Mar Ecol Prog Ser 37:249-257

Blight SP, Bentley TL, Lefevre D, Robinson C, Rowlands J, Williams PJ LeB (1995) Phasing of autotrophic and heterotrophic plankton metabolism in a temperate coastal ecosystem. Mar Ecol Prog Ser 128:61-75
Bokuniewicz H (1980) Groundwater seepage into Great South Bay, New York. Estuar Coast Mar Sci 10:437-444

Boyer GL, Szmyr DB, Alexander JA, LaRoche J (1999) Metabolic markers for the study of iron limitation in the brown tide alga Aureococcus anophagefferens. In: Weiler CS (ed) Limnology and oceanography: navigating into the next century. Abstract from ASLO meeting, Santa Fe, NM, February 1-5, 1999. ASLO, Waco, p 29

Breuer E, Sañudo-Wilhelmy SA, Aller RC (1999) Trace metals and dissolved organic carbon in an estuary with restricted river flow and a brown tide. Estuaries 22:603-615

Bricelj VM, Kuenstner SH (1989) Effects of 'brown tide' on the feeding physiology and growth of the bay scallops and mussels. In: Cosper EM, Bricelj VM, Carpenter EJ (eds) Novel phytoplankton blooms: causes and impacts of recurrent brown tides and other unusual blooms. SpringerVerlag, Berlin, p 491-510

Bricelj VM, Lonsdale DJ (1997) Aureococcus anophagefferens: causes and ecological consequences of brown tides in US mid-Atlantic coastal waters. Limnol Oceanogr 42: 1023-1038

Bronk DA, Glibert PM, Ward BB (1994) Nitrogen uptake, dissolved organic nitrogen release, and new production. Science 265:1843-1845

Bronk DA, Glibert PM, Malone TC, Banahan S, Sahlsten E (1998) Inorganic and organic nitrogen cycling in Chesapeake Bay: autotrophic versus heterotrophic processes and relationships to carbon flux. Aquat Microb Ecol 15: 177-189

Bruland KW (1980) Oceanographic distribution of cadmium, nickel, and copper in the North Pacific. Earth Planet Sci Lett 47:176-198

Bruland KW, Coale KH, Mart L (1985) Analysis of seawater for dissolved cadmium, copper, and lead: an intercomparison of voltammetric and atomic absorption methods. Mar Chem 17:285-300

Bruno SF, Staker RD, Sharma GM, Turner JT (1983) Primary productivity and phytoplankton size fraction dominance in a temperate North Atlantic estuary. Estuaries 6:200-211

Caron DA, Lim EL, Kunze H, Cosper EM, Anderson DM (1989) Trophic interactions between nano- and microzooplankton and the brown tide In: Cosper EM, Bricelj VM, Carpenter EJ (eds) Novel phytoplankton blooms: causes and impacts of recurrent brown tides and other unusual blooms. Springer-Verlag, Berlin, p 263-294

Caron DA, Lim EL, Miceli G, Waterbury JB, Valois FW (1991) Grazing and utlization of chroococcoid cyanobacteria and heterotrophic bacteria by protozoa in laboratory cultures and a coastal plankton community. Mar Ecol Prog Ser 76: 205-217

Carpenter EJ, Remsen CC, Watson SW (1972) Utilization of urea by marine phytoplankters. Limnol Oceanogr 17: 265-269

Carpenter EJ, Brinkhuis BM, Capone DG (1991) Primary production and nitrogenous nutrients in Great South Bay. In: Schubel JR, Bell TM, Carter HH (eds) The Great South Bay. SUNY Press, Stony Brook, NY, p 33-42

Cho BC (1988) Significance of bacteria in biogeochemical fluxes in the pelagic ocean. $\mathrm{PhD}$ dissertation, University of California at San Diego, La Jolla

Cho BC, Park MG, Shim JH, Azam F (1996) Significance of bacteria in urea dynamics in coastal surface waters. Mar Ecol Prog Ser 142:19-26

Coffin RB (1989) Bacterial uptake of dissolved free and combined amino acids in estuarine waters. Limnol Oceanogr 43:531-542

Cole JJ, Likens GE, Strayer DL (1982) Photosynthetically pro- 
duced dissolved organic carbon: an important carbon source for planktonic bacteria. Limnol Oceanogr 27: 1080-1090

Cosper EM (1987) Culturing the brown tide alga. Appl Phycol For $4: 3-5$

Cosper EM, and 7 others (1987) Recurrent and persistent 'brown tide' blooms perturb coastal marine ecosystem. Estuaries 10:284-290

Cosper EM, Dennison WC, Milligan AJ, Carpenter EJ, Lee C, Holzapfel J, Milanese L (1989) An examination of the environmental factors important to initiating and sustaining 'brown tide' blooms. In: Cosper EM, Bricelj VM, Carpenter EJ (eds) Novel phytoplankton blooms: causes and impacts of recurrent brown tides and other unusual blooms. Springer-Verlag, Berlin, p 317-340

Cosper EM, Lee C, Carpenter EJ (1990) Novel 'brown tide' blooms in Long Island embayments: a search for the causes. In: Graneli E, Sundstrom B, Edler L, Anderson DM (eds) Toxic marine phytoplankton. Elsevier, New York, p $17-28$

Cosper EM, Garry RT, Milligan AJ, Doall MH (1993) Iron, selenium, and citric acid are critical to the growth of the 'brown tide' microalga, Aureococcus anophagefferens. In: Smayda TJ, Shimizu Y (eds) Toxic phytoplankton blooms in the sea. Elsevier Science BV, Amsterdam, p 667-673

Cuhel RL, Ortner PB, Lean DRS (1984) Night synthesis of protein by algae. Limnol Oceanogr 29:731-744

Dennison WC, Marshall GJ, Wigand C (1989) Effects of 'brown tide' shading on eelgrass (Zostera marina) distributions. In: Cosper EM, Bricelj VM, Carpenter EJ (eds) Novel phytoplankton blooms: causes and impacts of recurrent brown tides and other unusual blooms. Springer-Verlag, Berlin, p 675-692

Droop MR (1974) Heterotrophy of carbon. In: Stewart WDP (ed) Algal physiology and biochemistry. University of California Press, Berkeley, p 530-559

Dzurica S, Lee C, Cosper EM, Carpenter EJ (1989) Role of environmental variables, specifically organic compounds and micronutrients, in the growth of Chrysophyte Aureococcus anophagefferens, the 'brown tide' microalgae. In: Cosper EM, Bricelj VM, Carpenter EJ (eds) Novel phytoplankton blooms: causes and impacts of recurrent brown tides and other unusual blooms. Springer-Verlag, Berlin, p 229-252

Eppley RW, Rogers JN, McCarthy JJ (1969) Half-saturation constants for uptake of nitrate and ammonium by marine phytoplankton. Limnol Oceanogr 14:912-920

Flegal AR, Smith GJ, Gill GA, Sañudo-Wilhelmy SA, Anderson, LCD (1991) Dissolved trace element cycles in the San Francisco Bay estuary. Mar Chem 36:329-363

Glibert PM (1982) Regional studies of daily, seasonal, and size fraction variability in ammonium remineralization. Mar Biol 70:209-222

Glibert PM (1993) The interdependence of uptake and release of $\mathrm{NH}_{4}{ }^{+}$and organic nitrogen. Mar Microb Food Webs 7:53-67

Glibert PM, Conley DJ, Fisher TR, Harding LW, Malone TC (1995) Dynamics of the 1990 winter/spring bloom in Chesapeake Bay. Mar Ecol Prog Ser 122:22-43

Gobler CJ (1995) The role of iron in the occurrence of Aureococcus anophagefferens blooms. Masters thesis, SUNY, Stony Brook, NY

Gobler CJ (1999) A biogeochemical investigation of Aureococcus anophagefferens blooms: interactions with organic nutrients and trace metals. PhD dissertation, SUNY, Stony Brook, NY

Gobler CG, Cosper EM (1996) Stimulation of 'brown tide' blooms by iron. In: Yasumoto T, Oshima Y, Fukuyo Y (eds) Harmful and toxic algal blooms. Intergovernmental Oceanographic Commission of UNESCO, Paris, p 321-324

Gobler CJ, Hutchins DA, Fisher NS, Cosper EM, Sañudo-Wilhelmy SA (1997) Release and bioavailability of C, N, P, Fe, and Se following viral lysis of a marine chrysophyte. Limnol Oceanogr 42:1492-1504

Goldman JC, Dennett MR (1991) Ammonium regeneration and carbon utilization by marine bacteria grown on mixed substrates. Mar Biol 109:369-378

Goldman JC, Caron DA, Dennett MR (1987) Regulation of gross growth efficiency and ammonium regeneration in bacteria by substrate C:N ratio. Limnol Oceanogr 32: 1239-1252

Griffiths RP, Caldwell BA, Morita RY (1982) Seasonal changes in microbial heterotrophicactivity in subarctic marine waters as related to phytoplankton primary productivity. Mar Biol 71:121-127

Guillard RRL (1973) Division rates. In: Stein JR (ed) Handbook of phycological methods, culture methods, and growth measurements. Cambridge Press, Cambridge, p 289-312

Hanson RB, Snyder J (1980) Glucose exchange in a salt marsh-estuary: biological activity and chemical measurements. Limnol Oceanogr 25:633-642

Ittekkot V, Brockmann U, Michaelis W, Degens ET (1981) Dissolved free and combined carbohydrates during a phytoplankton bloom in the northern North Sea. Mar Ecol Prog Ser 4:299-305

Jones MN (1984) Nitrate reduction by shaking with cadmium: alternative to cadmium columns. Wat Res 18:643-646

Kaufman ZG, Liveley JS, Carpenter EJ (1983) Uptake of nitrogenous nutrients by phytoplankton in a barrier island estuary: Great South Bay. Estuar Coast Shelf Sci 17: 483-493

Keller AA, Rice RL (1989) Effects of nutrient enrichment on natural populations of the brown tide phytoplankton Aureococcus anophagefferens (Chrysophyceae). J Phycol 25:636-646

Kepkay PE, Niven SEH, Milligan TG (1993) Low molecular weight and colloidal DOC production during a phytoplankton bloom. Mar Ecol Prog Ser 100:233-244

Kirchman DL, Keil RG, Wheeler PA (1990) Carbon limitation of ammonium uptake by heterotrophic bacteria in the subartic Pacific. Limnol Oceanogr 35:1258-1266

Kirchman DL, Suzuki Y, Garside C, Ducklow HW (1991) High turnover rates of dissolved organic carbon during a spring phytoplankton bloom. Nature 352:612-614

Kirchman DL, Ducklow HW, McCarthy JJ, Garside C (1994) Biomass and nitrogen uptake by heterotrophic bacteria during the spring phytoplankton bloom in the North Atlantic Ocean. Deep-Sea Res 41:879-895

LaRoche J, Nuzzi R, Waters R, Wyman K, Falkowski PG, Wallace DWR (1997) Brown tide blooms in Long Island's coastal waters linked to variability in groundwater flow. Global Change Biol 3:397-410

Lee S, Fuhrman J (1987) Relationship between biovolume and biomass of naturally derived marine bacterioplankton. Appl Environ Microbiol 53:391-421

Lewitus AJ, Caron DA (1991) Physiological responses of phytoflagellates to dissolved organic substrate additions. 1. Dominant role of heterotrophic nutrition in Poterioochromonas malhamensis (Chrysophyceae). Plant Cell Physiol 32:671-680

Lewitus AJ, Kana TM (1995) Light respiration in six estuarine phytoplankton species: contrasts under photoautotrophic and mixotrophic growth conditions. J Phycol 31:754-761 
Lively JS, Kaufman Z, Carpenter EJ (1983) Phytoplankton ecology of a barrier island estuary: Great South Bay, New York. Estuar Coast Shelf Sci 16:51-68

Lomas MW, Glibert PM, Berg GM, Burford M (1996) Characterization of nitrogen uptake by natural populations of Aureococcus anophagefferens (Chrysophyceae) as a function of incubation duration, substrate concentration, light, and temperature. J Phycol 32:907-916

Lonsdale DJ, Cosper EM, Kim WS, Doall MH, Divadeenam A, Jonasdottir SH (1996) Food web interactions in the plankton of Long Island bays, with preliminary observations on brown tide effects. Mar Ecol Prog Ser 134:247-263

Magdalena Santana-Cosicno J, Gonzalez-Davaila M, Lagler LM, Brand LE, Millero (1997) The influence of $\mathrm{Zn}, \mathrm{Al}$, and $\mathrm{Cd}$ on the uptake kinetics of Fe by alga. Mar Chem 59: 95-111

Mague TH, Friberg E, Hughes DJ, Morris I (1980) Extracellular release of carbon by marine phytoplankton: a physiological approach. Limnol Oceanogr 25:262-279

Mehran R (1996) Effects of A. anophagefferens on mircozooplankton grazing and growth rates in the Peconic Bays system, Long Island, New York. Masters thesis, SUNY, Stony Brook, NY

Miller CA, Glibert PM, Berg GM, Mulholland MR (1997) Effects of grazer and substrate amendments on nutrient and plankton dynamics in estuarine enclosures. Aquat Microb Ecol 12:251-261

Milligan AJ (1992) An investigation of factors contributing to blooms of the 'brown tide' Aureococcus anophagefferens (Chrysophyceae) under nutrient saturated (light limited) conditions. Masters thesis, SUNY, Stony Brook, NY

Milligan AJ, Cosper EM (1997) Growth and photosynthesis of the 'brown tide' microalga Aureococcus anophagefferens in subsaturating constant and fluctuating irradiance. Mar Ecol Prog Ser 153:67-75

Milligan KD, Cosper EM (1994) Isolation of virus capable of lysing the brown tide microalga, Aureococcus anophagefferens. Science 266:805-807

Mopper K, Dawson R, Liebezeit G, Ittekkot V (1980) Monosaccharide spectra of natural waters. Mar Chem 10:55-66

Mulholland MR, Glibert PM, Berg GM, Van Heukelem L, Pantoja S, Lee C (1998) Extracellular amino acid oxidation by microplankton: a cross-ecosystem comparison. Aquat Microb Ecol 15:141-152

Myklestad S, Holm-Hanson O, Varum KM, Volcani BE (1989) Rate of release of extracellular amino acids and carbohydrates from the marine diatom Chaetoceros affinis. J Plankton Res 11:763-773

Nagata T, Kirchman DL (1992) Release of macromolecular organic complexes by heterotrophic marine flagellates. Mar Ecol Prog Ser 83:233-246

Neilson AH, Lewin RA (1974) The uptake and utilization of organic carbon by algae: an essay in comparative biochemistry. Phycologia 13:227-264

Newell BS, Morgan B, Cundy J (1967) The determination of urea in seawater. J Mar Res 25:201-202

Nguyen RT, Harvey HR (1997) Protein and amino acid cycling during phytoplankton decomposition in oxic and anoxic waters. Org Geochem 27:115-128

Nixon SW, Pilson MEQ (1983) Nitrogen in estuarine and coastal marine ecosystems. In: Carpenter EJ, Capone DG (eds) Nitrogen in the marine environment. Academic Press, New York, p 411-458

Nixon SW, Granger SL, Taylor DI, Johnson PW, Buckely BA (1994) Subtidal volume fluxes, nutrient inputs and the brown tide-an alternative hypothesis. Estuar Coast Shelf Sci 39:303-312
Parker RR, Siebert J, Brown TJ (1975) Inhibition of primary productivity through heterotrophic competition for nitrate in a stratified estuary. J Fish Res Board Can 32:72-77

Parsons TR, Albright LJ, Whitney F, Wong CS, Williams PJ LeB (1980) The effect of glucose on the productivity of seawater: an experimental approach using controlled aquatic ecosystems. Mar Environ Res 4:229-242

Parsons TR, Maita Y, Lalli CM (1984) A manual of chemical and biological methods for seawater analysis. Pergamon Press, New York

Porter KG, Feig YS (1980) The use of DAPI for identifying and counting microflora. Limnol Oceanogr 25:943-948

Rich JH, Ducklow HW, Kirchman DL (1996) Concentrations and uptake of neutral monosaccharides along $140^{\circ} \mathrm{W}$ in the eqatorial Pacific: contribution of glucose to heterotrophic bacterial activity and DOM flux. Limnol Oceanogr 41:595-604

Ryther JH, Dunstan WM (1971) Nitrogen, phosphorus, and eutrophication in the coastal marine environment. Science 171:1008-1013

Sanders R, Purdie DA (1998) Bacterial response to blooms dominated by diatoms and Emiliania huxleyi in nutrient enriched mesocosms. Estuar Coast Shelf Sci 46A:35-48

Sañudo-Wilhelmy SA, Rivera-Duarte I, Flegal AR (1996) Distribution of colloidal trace metals in the San Francisco Bay estuary. Geochim Cosmochim Acta 60:4933-4944

Schaffner R (1999) The role of suspension feeding bivalves in the initiation and control of Aureococcus anophagefferens blooms. Masters thesis, SUNY, Stony Brook, NY

SCDHS (1985-1998) Suffolk County Department of Health Services, Office of Ecology's annual reports of water quality in the Peconic Estuary. SCDHS, Riverhead, NY

Sharp JH (1974) Improved analysis for particulate organic carbon and nitrogen in seawater. Limnol Oceanogr 19: 984-989

Sherr BF, Sherr EB, Andrew TL, Fallon RD, Newell SY (1986) Trophic interactions between heterotrophic protozoa and bacterioplankton in estuarine waters analyzed with selective metabolic inhibitors. Mar Ecol Prog Ser 32: 169-179

Shiah FK, Ducklow HW (1995) Regulation of bacterial abundance and production by substrate supply and bacterivory: a mesocosm study. Microb Ecol 30:239-255

Smayda TJ, Villareal TA (1989) The 1985 brown tide and the open phytoplankton niche in Narragansett Bay during the summer. In: Cosper EM, Bricelj VM, Carpenter EJ (eds) Novel phytoplankton blooms: causes and impacts of recurrent brown tides and other unusual blooms. Springer-Verlag, Berlin, p 317-340

Smith SV (1984) Phosphorus versus nitrogen limitation in the marine environment. Limnol Oceanogr 29:1149-1160

Spies A, Nutbrown D, Parsons TR (1983) An experimental approach to estuarine microplankton ecology. Estuar Coast Shelf Sci 17:97-105

Stumm W, Morgan JJ (1981) Aquatic chemistry. John Wiley \& Sons, London

Sugimura Y, Suzuki Y (1988) A high temperature catalytic oxidation method for the determination of non-volatile dissolved organic carbon in seawater by direct injection of a liquid sample. Mar Chem 24:105-131

Sunda WG (1994) Trace metal/phytoplankton interactions in the sea. In: Bidoglio G, Stumm W (eds) Chemistry of aquatic systems: local and global perspectives. Kluwer, Brussels, p 213-247

Sunda WG, Huntsman SA (1995) Iron uptake and growth limitation in coastal and oceanic phytoplankton. Mar Chem 50:189-206 
Turley CM (1985) Biological studies in the vicinity of a shallow-sea tidal mixing front. IV. Seasonal and temporal distribution of urea and its uptake by phytoplankton. Phil Trans R Soc (Ser B) 310:471-500

Wheeler PW, Kirchman DL (1986) Utilization of inorganic and organic nitrogen by bacteria in marine systems. Limnol Oceanogr 31:998-1009

Editorial responsibility: Otto Kinne (Editor),

Oldendorf/Luhe, Germany
Williams PJLeB (1975) Biological and chemical aspects of dissolved organic matter in the sea. In: Riley JP, Skirrow G (eds) Chemical oceanography. Academic Press, London p 301-363

Wright RT, Hobbie JE (1966) Use of glucose and acetate by bacteria and algae in aquatic ecosystems. Ecology 47: $447-464$

Submitted: January 17, 2000; Accepted: June 20, 2000

Proofs received from author(s): November 20, 2000 